\title{
Peran Ulama \\ dalam Pemberdayaan Masyarakat Marjinal:
}

\section{Oleh:}

\author{
DR. H. AHMAD ASMUNI. MA. ${ }^{1}$ \\ azifa.312@gmail.com
}

\begin{abstract}
Abstrak
Manusia dengan potensi akal yang dikaruniakan oleh Allah swt kepadanya, mestinya dapat mengantarkannya pada kehidupan yang bermakna dan sejahtera. Namun demikian, pada kenyataannya, ada sekelompok manusia yang termarjinalkan dari kelompok lainnya. Kelompok yang demikian dikenal dengan istilah kelompok marjinal atau masyarakat marjinal. Kelompok marjinal terbagi menjadi dua yakni; kelompok marjinal yang tradisional dan kelompok marjinal yang modern. Pada dasarnya kedua kelompok marjinal tersebut memerlukan solusi untuk bisa lepas dari ketermarjinalannya. Oleh karena itu, kelompok marjinal tersebut memerlukan sosok yang mampu menjadi perantara bagi terlepasnya mereka dari "symbol" sebagai masyarakat marjinal yang disandangnya. Dalam hal ini salah satu sosok yang dibutuhkan oleh mereka untuk bisa lepas dari symbol ketermarjinalan adalah sosok ulama yang dengan dakwahnya mampu mengantarkan mereka terlepas dari stempel sebagai masyarakat marjinal.
\end{abstract}

Kata Kunci: Ulama, Pemberdayaan, dan Masyarakat Marjinal.

\section{Abstract}

Man with the potential of reason which Allah granted to him, should be able to deliver it to a meaningful and prosperous life. However, in reality, there is a group of people marginalized from other groups. Such groups are known by the term marginal or marginal society. Marginalized groups are divided into two namely; Traditional marginalized groups and modern marginalized groups. Basically, the two marginal groups need a solution to get out of ketermarjinalannya. Therefore, the marginal group needs a figure capable of intermediary for their release from the "symbol" as the marginal society it bears. In this case one of the figures required by them to get away from the symbol of ketermarjinalan is a figure of scholars who with dakwah able to deliver them regardless of the stamp as a marginal society.

Keywords: Ulama, Empowerment, and Marginal Society.

${ }^{1}$ Penulis adalah dosen Fakultas Ushuluddin Adab dan Dakwah (FUAD) Prodi dakwah Institut Agama Islam (IAIN) Syekh Nurjati Cirebon Jawa Barat. 
masalah takdir. Paling tidak agar kaum marjinal bisa memahami bahwa ketermarjinalan mereka sesungguhnya bukan merupakan takdir dari allah swt dan bukan pula warisan dari orang tua atau nenek moyang mereka. Dan oleh karena itu, untuk bisa terlepas dari setatus mereka sebagai masyarakat marjinal maka perlu adanya usaha, kerja keras (pemberdayaan diri) dan dibarengi dengan doa yang maksimal serta tawakkal kepada Allah swt.

\section{B. ULAMA}

\section{Definisi Ulama}

Posisi ulama sungguh merupakan posisi yang sangat prestisius. Hal ini selain karena posisi ulama yang dianggap sebagai pewaris nabi juga karena Allah swt menyebut-nyebut ulama dalam Al-Quran. hal tersebut dengan jelas betapa allah swt mengukir kata ulama sebanyak dua kali dalam Al-Quran yaitu dalam surat asySyu'ara' ayat 197 dan Faathir ayat 28.

Artinya: "Dan apakah tidak cukup menjadi bukti bagi mereka bahwa para ulama Bani Israil mengetahuinya?' .

Artinya: Sesungguhnya yang takut kepada Allah di antara hambahamba-Nya, hanyalah ulama.

Sesungguhnya Allah Maha Perkasa lagi Maha Pengampun. ${ }^{4}$

Ayat di atas menurut badrudin HSubky mengisyaratkan bahwa ulama merupakan hamba Allah yang beriman, bertakwa, menguasai ilmu kauniyah dan tanziliyah, berpandangan hidup luas, dan bcribadah dengan landasan rasa takut kepada Allah SWT. Takut

\footnotetext{
${ }^{2}$ QS. asy-Syu'ara': 197.

${ }^{3}$ Yang dimaksud dengan ulama dalam ayat Ini ialah orang-orang yang mengetahui kebesaran dan kekuasaan Allah.

${ }^{4}$ QS. Faathir: 28
}

\section{A. PENDAHULUAN}

Sejak dulu hingga sekarang masih ditemukan masyarakat marjinal. Seperti; para gelandangan dan anak jalanan. Eksistensi mereka akan terus eksis sepanjang mereka tidak mau berusaha merubah dirinya sendiri. Hal yang membuat mereka eksisi sebagai penyandang symbol masyarakat marjinal diantaranya adalah paham teologi mereka yang bersifay Jabbariyyah, dimana mereka menganggap bahwa eksistensi mereka tak lain dan tak bukan karena merupakan takdir dari allah atau keyakinan mereka bahwa keberadaan mereka merupakan warisan dari orangtua mereka yang juga penyandang sebagai masyarakat marjinal. Paham teologi (pola pikir) yang demikian harus diluruskan. Oleh karena itu, ulama dengan dakwahnya --dalam konteks ini-sangat dibutuhkan.Kehadiran ulama terkait pelurusan paham/pemikiran jabbariyah yang terpatri pada masyarakat marjinal --terutama masyarakat marjinal tradisional) perlu dibongkar dan diganti dengan teologi yang tidak fatalis atau jabbari. Dengan adanya dakwah ulama yang mampu memahamkan paham teologi rasional maka akan sangat mungkin masyarakat marjinal tersebut -dengan usahanya yang sangat sungguh-sungguh- akan dapat melepaskan symbol ketermarjinalannya.

Dalam menghadapi masyarakat marjinal, ulama perlu melakaukan penanaman teologi rasional agar mereka mampu memahami bahwa symbol marjinal yang selama ini melekat pada mereka bukan takdir. Oleh karena itu, Dalam aplikasi dakwah kepada kelompok marjinal, ulama -terutama-harus mampu memahamlan mereka kepada teologi terutama yang berkaitan dengan 
Allah sangat mendalam disebabkan ma'rifatnya."

d. Ibnu Katsir: "Ulama adalah yang benar-benar ma'rifatnya kepada Allah sehingga mereka takut kepada-Nya. Jika ma'rifatnya sudah sangat dalam maka sempurnalah takutnya kepada Allah."

e. Sayyid Quthub : "Ulama adalah orang yang senantiasa berpikir kritis akan Kitab Al-Qur'an (yang mendalam maknanya) sehingga mereka akan ma'rifat secara hakiki kepada Allah. Mereka ma'rifat

f. Syekh Nawawi al-Bantani : "Ulama adalah orang-orang yang mcnguasai segala hukum syara' untuk menetapkan sahnya agama, baik penetapan sah i'tikad maupun amal syari'at Iainnya." Sedang-kan Dr. Wahbah az-Zuhaili bcrkata, "Secara naluri, ulama adalah orang-orang yang mampu menganalisa alam fenomena untuk kepentingan hidup dunia dan akhirat serta takut ancaman Allah jika terjerumus ke dalam kenistaan. Orang yang maksiat hakikatnya bukan ulama.".

g. M. Quraish Shihab: Ulama ialah orang yang mempunyai pengetahuan tentang ayat-ayat Allah, baik yang bersifat kawniyyah maupun yang bersifat qur'aniyyah. ${ }^{8}$

\section{Kriteria Ulama}

Ulama sebagai pewaris Nabi mempunyai tugas dan tanggung jawab yang besar dalam membimbing mengayomi segenap umat pada zamannya. ${ }^{9}$ Oleh karena itu tidak setiap orang begitu mudahnya mengklaim

${ }^{7}$ Ibid., hlm., 45-46

8 M. Quraish Shihab. Membumikan Al-Quran: Fungsi dan Peran Wahyu dalam Kehidupan Masyarakat. Bandung : Mizan. 1992., hlm 382

\footnotetext{
${ }^{9}$ Badruddin HSubky. Dilema Ulama.,
} Op., Cit., hlm., 22 (khasyyah), ${ }^{5}$ merupakan sifat khusus ulama. ${ }^{6}$

Di kalangan umat Islam, kata ulama mcnimbulkan berbagai persepsi sehingga belum ada definisi yang baku.

Dalam upaya merumuskan kata ulama, menurut badrudin HSubky hendaknya merujuk kepada pendapat para mufassir salaf (sahabat dan tabi'in) yang dekat dengan pusat ilmu keislaman.Beberapa di antara pendapat mereka disajikan berikut ini. Rumusan ini diakui kcabsahannya oleh sebagian besar pimpinan pesantren di Indonesia.

a. Imam Mujahid : "Ulama adalah orang yang hanya takut kepada Allah SWT." Malik bin Anas pun menegaskan, "Orang yang tidak takut kepada Allah bukanlah ulama."

b. Hasan Basri : "Ulama adalah orang yang takut kepada Allah disebabkan perkara gaib, suka kepada setiap sesuatu yang disukai Allah, dan menolak segala sesuatu yang dimurkai-Nya."

c. Ali ash-Shabuni: "Ulama adalah orang yang rasa takumya kepada

5 Sejumlah mufassir menjelaskan pengertian kata khasyyah dalam kitab tafsir mereka masing-masing. Said bin Jubair mengatakan bahwa khasyyah adalah rasa takut kepada Allah yang menghalangi seseorang dari perbuatan dosa kcpada-Nya. Menurut Ali Husain al-Jurjani, khasyyah ialah rasa takut pada tindakan yang dibenci Allah. Khasyyah muncul jika seseorang merasa ia melakukan banyak dosa atau mendapat pengaruh ma'rifat dari Allah SWT. Yang bisa khasyyah kepada Allah secara hakiki hanya para nabi karena ma'rifatnya kepada Allah sangat mendalam.

Pendapat mufassir itu menunjukkan, khasyyah merupakan kriteria khusus bagi seorang ulama. Namun demikian, sulit menemukan kriteria ulama yang komprehensif.

${ }^{6}$ Badruddin HSubky. Dilema Ulama., op.,cit., hlm., 44 


\section{PEMBERDAYAAN MASYARAKAT \\ 1. PEMBERDAYAAN \\ a. Definisi Pemberdayaan}

Istilah pemberdayaan mulai tahun 1990-an menjadi trend dalam pembangunan. Kegagalan konsep pembangunan yang menekankan pada aspek makro, telah diyakini bahwa konsep pemberdayaan sebagai alternatif ampuh untuk penuntasan pembangunan. Pemerintah pusat di beberapa kementerian secara tegas membentuk berbagai lembaga pemberdayaan, bahkan ada kementerian yang mengkhususkan pada pemberdayaan perempuan. Ada juga program nasional yang fokus pada pemberdayaan yaitu Program Nasional Pemberdayaan Masyarakat-Mandiri (PNMP Mandiri). ${ }^{11}$ Begitu pula di tingkat pemerintah daerah provinsi dan kabupaten/kota telah membentuk lembaga atau satuan kerja (Satker) yang menangani khusus tentang pemberdayaan masyarakat. Banyak pula pemerintah daerah yang langsung membentuk lembaga dengan nama pemberdayaan, misalnya: Badan Pemberdayaan Masyarakat (Bapimas), atau Lembaga Pemberdayaan Masyarakat, Pada tingkat desa atau kelurahan sudah dibentuk Lembaga Pemberdayaan Masyarakat Desa atau Lembaga Pemberdayaan Masyarakat Kelurahan.

Ilmu sosial tradisional menekankan bahwa kekuasaan/ berkaitan dengan pengaruh dan kontrol. Pengertian ini mengasumsikan bahwa kekuasaan sebagai sesuatu yang tidak berubah atau tidak dapat dirubah.

11 Oos. M. Anwas, Pemberdayaan Masyarakat di Era Global. Bandung : Alfabeta. 2014., hlm., 2. Lihat juga Harry Hikmat. Strategi Pemberdayaan Masyarakat. Bandung Humaniora., 2013., hlm., 1 dirinya sebagai ulama. Seorang yang dianggap sebagai ulama setidaknya harus memiliki kriteria sebagai berikut:

a. Menguasai ilmu agama Islam (fafaqquh fiddin) dan sanggup membimbing umat dengan memberikan bekal ilmu-ilmu keislaman yang bersumber dari AlQur'an, hadits, ijma', dan qiyas.

b. Ikhlas melaksanakan ajaran Islam.

c. Mampu menghidupkan Sunnah Rasul dan mengembangkan Islam secara kaffah.

d. Berakhlak luhur, berpikir kritis, aktif mendorong masyarakat melaku-kan perbuatan positif, bertanggung jawab, dan istiqamah.

e. Berjiwa besar, kuat mental dan fisik, tahan uji, hidup sederhana, amanah, beriradah, berjamaah, tawadhu', kasih sayang terhadap sesama, mahabah, serta khasyyah dan tawakal kepada Allah SWT.

f. Mengetahui dan peka terhadap situasi zaman serta mampu menjawab setiap persoalan untuk kepentingan Islam dan umatnya.

g. Berwawasan luas dan mcnguasai beberapa cabang ilmu demi pengembangannya. Menerima pendapat orang lain yang tidak bertentangan dengan Islam dan bersikap tawadhu'. ${ }^{10}$

Nampaknya, definisi di atas belum dikenal secara luas oleh umat Islam. Sebab, di tengah masyarakat berlangsung kebiasaan mcmberikan gelar ulama kepada seseorang yang belum memenuhi kriteria di atas.
${ }^{10}$ Ibid.,, hlm., 47 
cara pemberdayaan yang ditulis oleh Edi Suharto dalam bukunya yang berjudul Membangun Masyarakat Member-dayakan Rakyat. ${ }^{13}$

a. Pemberdayaan bertujuan untuk meningkatkan kekuasaan orangorang yang lemah atau tidak beruntung (Ife, 1995).

b. Pemberdayaan adalah sebuah proses dengan mana orang menjadi cukup kuat untuk berpartisipasi dalam, berbagi pengontrolan atas, dan mempengaruhi lerhadap, kejadiankejadian ini, hingga lembaga yang mau memrnuhi kehidupannya. I'emberdayaan menekankan bahwa orang memperoleh keterampilan, pengetahuan, dan kekuasaan yang cukup untuk mempengaruhi kehidupannya dan kehidupan orang lain yang menjadi perhatiannya (Parsons, et.al., 1994).

c. Pemberdayaan menunjuk pada usaha pengalokasian kembali kekuasaan melalui pengubahan struktur sosial (Swift dan Levin, 1987).

d. Pemberdayaan adalah suatu cara dengan mana rakyat, organisasi, dan komunitas diarahkan agar mampu menguasai (atau berkuasa atas) kehidupannya (Rappaport, 1984).

Berdasarkan uraian di atas dapat dipahami bahwa pemberdayaan adalah sebuah proses dan lujuan. Sebagai proses, pemberdayaan adalah serangkaian kegiatan untuk masyarakat, termasuk individuindividu yang mengalami masalah kemiskinan. Sebagai lujuan, maka pemberdayaan menunjuk pada keadaan atau hasil yang ingin dicapai oleh scbuah perubahan sosial; yaitu masyarakat yang berdaya, memiliki kekuasaan atau mempunyai pengetahuan dan kemampuan dalam

${ }^{13}$ Ibid., 27.
Kekuasaan sesungguhnya tidak terbatas pada pengertian di atas. Kekuasaan tidak vakum dan terisolasi. Kekuasaan senantiasa hadir dalam konteks relasi sosial antar manusia. Kekuasaan tercipta dalam relasi sosial. Karena itu, kekuasaan dan hubungan kekuasaan dapat berubah. Dengan pemahaman kekuasaan seperti ini, pemberdayaan sebagai sebuah proses perubahan kemudian memiliki konsep yang bermakna. Dengan kata lain, kemungkinan terjadinya proses pemberdayaan akan sangat tergantung pada dua hal:

1. Bahwa kekuasaan dapat berubah. jika kekuasaan tidak dapat berubah, pemberdayaan tidak mungkin terjadi dengan cara apapun.

2. Bahwa kekuasaan dapat diperluas. Konsep ini menekankan pada pengertian kekuasaan yang tidak statis, melainkan dinamis. ${ }^{12}$

Pemberdayaan menunjuk pada kemampuan orang, khususnya kelompok rentan dan lemah sehingga mereka memiliki kekuatan atau kemampuan dalam (a) memenuhi kebutuhan dasarnya sehingga mereka memiliki kebebasan (freedom), dalam arti bukan saja bebas untuk mengemukakan pendapat, melainkan bebas dari kelaparan, bebas dari kebodohan, bebas dari kesakitan; (b) menjangkau sumber-sumber produktif yang memungkinkan mereka dapat meningkatkan pendapatan-nya dan memperoleh barang-barang dan jasajasa yang mereka perlukan; dan (c) berpartisipasi dalam proses pembangunan dan keputusankeputusan yang mempengaruhi mereka. Berikut ini pengertian pemberdayaan menurut beberapa ahli dilihat dari tujuan, proses, dan cara-

\footnotetext{
${ }^{12}$ Edi Suharto. Membangun Masyarakat., Op., cit., ., 28.
} 
1). Kebebasan mobilitas: kemampuan individu untuk pergi ke luar rumah atau wilayah tempal tinggalnya, seperti ke pasar, fasilitas medis, bioskop, rumah ibadah, ke rumah tetangga. Tingkat mobilitas ini dianggap tinggi jika individu mampu pergi sendirian.

2). Kemampuan membeli komoditas kecil: kemampuan individu untuk membeli barang-barangkebutuhan keluargasehari-hari (beras, minyak tanah, minyak goreng, bumbu); kebutuhan dirinya (minyak rambut, sabun mandi, rokok, bedak, sampo). Individu dianggap mampu melakukan kegiatan ini terutama jika ia dapat membuat keputusan sendiri tanpa meminta ijin pasangannya; terlebih jika ia dapat membeli barang-barangtersebut dengan menggunakan uangnya sendiri.

3). Kemampuan membeli komoditas besar: kemampuan individu untuk membeli barangbarangsekunderatau tersier, seperti lemari pakaian, TV, radio, koran, majalah, pakaian keluarga. Seperti halnya indikator di atas, poin tinggi diberikan terhadap individu yang dapat membuat keputusan sendiri tanpa meminta ijin pasangannya; terlebih jika ia dapat membeli barang-barang tersebut dengan menggunakan uangnya sendiri.

4). Terlibat dalam pembuatan keputusan-keputusan rumah tangga: mampu membuat keputusan secara sendiri maupun bersama suami/istri mengenai keputusan-keputusan keluarga, misalnya mengenai renovasi rumah, pembelian kambing untuk diternak, memperoleh kreditusaha.

5). Kebebasan relatif dari dominasi keluarga: responden ditanya mengenai apakah dalam satu tahun terakhir ada seseorang (suami, istri, memenuhi kebutuhan hidupnya baik yang bersifat fisik, ekonomi, maupun sosial seperti memiliki kepercayaan diri, mampu menyampai-kan aspirasi, mempunyai mata pencaharian, berpartisipasi dalam kegiatan sosial, dan mandiri dalam melaksanakan tugas-tugas kehidup-annya. Pengertian pemberdayaan sebagai tujuan seringkali digunakan sebagai indikator keberhasilan pemberdayaan sebagai sebuah proses.

\section{b. Indikator Keberdayaan}

Untuk mengetahui fokus dan tujuan pemberdayaan secara operasional, maka perlu diketahui berbagai indikator keberdayaan yang dapat menunjukkan seseorang itu berdaya atau tidak. Sehingga ketika sebuah program pemberdayaan sosial diberikan, segenap upaya dapat dikonsentrasikan pada aspek-aspek apa saja dari sasaran perubahan (misalnya keluarga miskin) yang perlu dioptimalkan.

Schuler, Hashemi dan Riley sebagaimana dijelaskan oleh Suharto telah mengembangkan delapan indikator pemberdayaan, yang mereka sebut sebagai empowerment index atau indeks pemberdayaan. ${ }^{14}$ Keberhasilan pemberdayaan masyarakat dapat dilihat dari keberdayaan mereka yang menyangkut kemampuan ekonomi, kemampuan mengakses manfaat kesejahteraan, dan kemampuan kultural dan politis. Ketiga aspek tersebut dikailkan dengan empat dimensi kekuasaan. Yaitu: 'kekuasaan di dalam' (power within), kekuasaan untuk (power to) 'kekuasaan atas (power over), dan 'kekuasaan dengan' (power with). Adapun indikator pemberdayaan adalah:

\footnotetext{
14 Ibid.
} 
kemampuan diri klien, hal ini bukanlah strategi utama pemberdayaan. Namun demikian, tidak semua intervensi pekerjaan sosial dapat dilakukan melalui kolektivitas. Dalam beberapa situasi, strategi pemberdayaan dapat saja dilakukan secara individual; meskipun pada gilirannya strategi ini pun tetap berkaitan dengan kolektivitas, dalam arti mengkaitkan klien dengan sumberatau sistem lain di luardirinya. Dalam konteks pekerjaan sosial, pemberdayaan dapat di lakukan melalui tiga aras atau matra pemberdayaan (empowerment setting): mikro, mezzo, dan makro.

1. Aras Mikro. Pemberdayaan dilakukan terhadap klien secara individu melalui bimbingan, konseling, stress management, crisis intervention. Tujuan utamanya adalah membimbing atau melatih klien dalam menjalankan tugastugas kehidupannya. Model ini sering disebut sebagai Pendekatan yang Berpusat pada Tugas (task centered approach).

2. Aras Mezzo. Pemberdayaan dilakukan terhadap sekelompok klien. Pemberdayaan dilakukan dengan menggunakan kelompok sebagai media intervensi. Pendidikan dan pelatihan, dinamika kelompok, biasanya digunakan sebagai strategi dalam mcmngkatkan kesadaran, pengetahuan, keterampilan dan sikap-sikap klien agar memiliki kemampuan memecahkan permasalahan yang dihadapinya.

3. Aras Makro. Pendekatan ini disebut juga sebagai Strategi Sistem Besar (large-system strategy), karena sasaran perubahan diarahkan pada sistem lingkungan yang lebih luas. Perumusan kebijakan, perencanaan sosial, kampanye, aksi sosial, lobbying, pengorganisasian anak-anak, mertua) yang mengambil uang, tanah, perhiasan dari dia tanpa ijinnya; yang melarang mempunyai anak; atau melarang bekerja di luar rumah.

6). Kesadaran hukum dan politik: mengetahui nama salah seorang pegawai pemerintah desa/kelurahan; seorang anggota DPRD setempat; nama presiden; mengetahui pentingnya memiliki surat nikah dan hukum-hukum waris.

7). Keterlibatan dalam kampanye dan protes-protes: seseorang dianggap 'berdaya' jika ia pernah terlibat dalam kampanye atau bersama orang lain melakukan protes, misalnya, terhadap suami yang memukul istri; istri yang mengabaikan suami dan keluarganya; gaji yang tidak adil; penyalahgunaan bantuan sosial; atau penyalahgunaan kekuasa-an polisi dan pegawai pemerintah.

8). Jaminan ekonomi dan kontribusi terhadap keluarga: memiliki rumah, tanah, asset produktif, tabungan. Seseorangdianggap memiliki poin tinggi jika ia memiliki aspek-aspek tersebut secara sendiri atau terpisah dari pasangannya. ${ }^{15}$

\section{c. Strategi Pemberdayaan}

Parsons et.al. (1994:112-113) sebagaimana dikutip oleh Suharto, menyatakan bahwa proses pemberdayaan umumnya dilakukan secara kolektif. Menurutnya, tidak ada literature yang menyatakan bahwa proses pemberdayaan terjadi dalam retasi satu-lawan-satu antara pekerja sosial dan klien dalam setting pertolongan perseorangan. Meskipun pemberdayaan seperti ini dapat meningkatkan rasa percayadiri dan

${ }^{15}$ Edi Suharto. Membangun Masyarakat Ibid., hlm., 27., hlm., 218-219 
dan mencegah terjadinya eksploitasi kelompok kuat terhadap kelompok lemah. Pemberdayaan harus diarahkan pada penghapusan segala jenis diskriminasi dan dominasi yang tidak menguntungkan rakyat kecil.

4. Penyokongan: memberikan bimbingan dan dukungan agar masyarakat mampu menjalankan peranan dan tugas-tugas kehidupannya. Pem-berdayaan harus mampu menyokong masyarakat agar tidak lerjatuh ke dalam keadaan dan posisi yang semakin lemah dan terpinggirkan.

5. Pemeliharaan: Memelihara kondisi yang kondusif agar tetap terjadi keseimbangan distribusi kckuasaan antara berbagai kelompok dalam masyarakat. Pemberdayaan harus mampu menjamin keselarasan dan keseimbangan yang memungkinkan setiap orang memperoleh kesempatan berusaha.

Adapun teknik pemberdayaan yang dapat dilakukan untuk memberdayakan masyarakat menurut Dubois dan Miley (1992:211) sebagaimana dikutip Suharto adalah ;

1. Membangun relasi pertolongan yang: (a) merefleksikan respon empati; (b) menghargai pilihan dan hak klien menentukan nasibnya sendiri (sell-determination); (c) menghargai perbedaan dan keunikan individu; $(d)$ menekankan kerjasama klien (client partnerships).

2. Membangun komunikasi yang: (a) menghormati martabat dan harga diri klien; (b) mempertimbangkan kcragaman individu; (c) berfokus pada klion; $(d)$ menjaga kerahasiaan klien.

3. Terlibat dalam pcmecahan masalah yang: (a) memperkuat parti si pasi klien dalam semua aspek proses masyarakat, manajemen konflik, adalah beberapa strategi dalam pendekatan ini. Strategi Sistem Besar memandang klien sebagai orang yang memiliki kompetensi untuk memahami situasi-situasi mereka sendiri, dan untuk memilih serta menentukan strategi yang tepat untuk bertindak. ${ }^{16}$

\section{d. Pendekatan Pemberdayaan}

Pelaksanaan proses dan pencapaian tujuan pemberdayaan di atas dicapai dengan melalui penerapan pendekatan pemberdayaan yang dapat disingkat menjadi 5P, yaitu: Pemungkinan, Penguatan, Perlindungan, Penyokongan dan Pemeliharaan. ${ }^{17}$

1. Pemungkinan: menciptakan suasana atau iklim yang memungkinkan potensi masyarakat berkembang secara optimal. Pemberdayaan harus mampu membebaskan masyarakat dari sekat-sekat kultural dan struktural yang menghambat.

2. Penguatan: memperkuat pengetahuan dan kemampuan yang dimiliki masyarakat dalam memecahkan masalah dan memenuhi kebutuhankebutuhannya. Pemberdayaan harus mampu menumbuhkembangkan segenap kemampuan dan kepercayaan diri masyarakat yang menunjang kemandirian mereka.

3. Perlindungan: melindungi masyarakat terutama kelompokkelompok lemah agar tidak tertindasoleh kelompok kuat, menghindari terjadinya persaingan yang tidak seimbang (apalagi tidak sehat) antara yang kuat dan lemah,

\footnotetext{
${ }^{16}$ Edi Suharto. Membangun Masyarakat Ibid., hlm., 27., hlm., 218-219

${ }^{17}$ Ibid., hlm.,
} 
adalah kelompok manusia yang cukup lama hidup dan bekerja sama sehingga dapat mengorganisasikan dirinya dan berpikir mengenai dirinya sebagai kesatuan sosial yang mempunyai batasbatas tertentu. $^{21}$

Sedangkan masyarakat menurut Murtadha Muthahhari adalah kelompok manusia yang saling terkait oleh sistem-sistem, adat istiadat, ritus-ritus dan hukum-hukum khas yang hidup bersama. $^{22}$

Berdasarkan uraian di atas dapat dipahami bahwa yang dimaksud dengan masyarakat adalah suatu kelompok manusia yang digunakan untuk menggambarkan ikatan atau interaksi antara pihak-pihak yang bersahabat. Dalam arti asosiasi, sebuah masyarakat adalah tubuh individu digariskan oleh batas-batas saling ketergantungan fungsional, terdiri dari karakteristik seperti identitas nasional atau budaya, solidaritas sosial, bahasa atau organisasi hierarkis. Lebih luasnya, masyarakat merupakan infrastruktur ekonomi, sosial, atau industri, terdiri dari kumpulan individu bervariasi.

\section{b. Definisi Masyarakat Marjinal.}

Marjinal berasal dari bahasa Inggris 'marginal' yang berarti jumlah atau efek yang sangat kecil. Artinya, marjinal adalah suatu kelompok yang jumlahnya sangat kecil atau bisa juga diartikan sebagai kelompok pra-sejahtera. Marjinal juga identik denganmasyarakat kecil atau kaum yang terpinggirkan. ${ }^{23}$

21 Sidi Gazalba, Masyarakat Islam., op., cit., hlm. 5 .

${ }^{22}$ Murtadha Muthahhari, Masyarakat dan Sejarah, (Bandung: Mizan, 1993), hlm. 15.

23

http://www.google.co.id/\#q=arti+masyarakat +marjinal\&spf=1496156529661 diakses pemecahan masalah; (b) menghargai hak-hak klien; (c) merangkai tantangan-Lantangan sebagai kesempatan belajar; (d) melibatkan klien dalam pembuatan keputusan dan evaluasi.

4. Merefleksikan sikap dan nilai profesi pekerjaan sosial melalui: (a) ketaatan terhadap kode etik profesi; (b) keterlibatan dalam pengembangan profesional, riset, dan perumusan kebijakan; (c) penerjemahan kesulitan-kesulitan pribadi ke dalam isu-isu publik; $(d)$ penghapusan segala bentukdiskriminasi dan ketidaksetaraan kesempatan. ${ }^{18}$

\section{MASYARAKAT MARJINAL}

a. Definisi Masyarakat

Istilah masyarakat berasal dari bahasa Arab "syarikah" yang berarti perkumpulan. ${ }^{19}$ Istilah masyarakat yang berasal dari kata syarikah tersebut lebih dikenal dan bcgitu familiar bagi masyarakat Indonesia dibandingkan istilah Arab al-mujtama' yang berarti masyarakat.

Kata masyarakat menurut W.J.S. Poerwadarminta dalam Kamus Besar Bahasa Indonesia diartikan sebagai pergaulan hidup manusia (himpunan orang yang hidup bersama di suatu tempat dengan ikatan-ikatan aturan yang tentu). ${ }^{20}$

Ralph Linton yang dikutip oleh Sidi Gazalba, menjelaskan bahwa yang dimaksud dengan istilah masyarakat

18 Edi Suharto. Pembangunan Kebijakan sosial dan Pekerjaan sosial; Spektrum Pemikiran : Bandung ; Lembaga Studi Pembangunan STKS (LSP-STKS). 1996., hlm., 68

19 Sidi Gazalba, Masyarakat Islam Pengantar Sosiologi dan Sosiografi, (|akarra: Bulan Bintang, 1976), hlm. 1

20 W.J.S. Poerwadarminta. Kamus Umum Bahasa Indonesia, Jakarta : Balai Pustaka 1991., hlm., 636 
2. Termasuk: Buruh anak, ketidaksetaraan gender, ekslusi sosial, kekerasan hak asasi

b). Secara Infastruktur:

1. Individu atau kelompok masyarakat dari kultur manapun ia perasal, ketika keberadaan mereka dalam kehidupan secara geografis mengalami kesulitan pada akses untuk mendapatkan air bersih, jarak transportasi yang tak terjangkau, ataupun akses pada Bank dan komunikasi yang sulis, maka kelompok masyarakat ini bisa dikatakan ma rginal. Kebanyakan kelompok masyarakat demikian biasanya terisolir dengan masyarakat kebanyakan.

2. Seperti akses pada air bersih, jarak terhadap fasilitas transportasi, Bank, komunikasi dan suplai energi lainnya.

c). Secara Kesehatan:

1. Kelompok Masyarakat yang harapan hidupnya rendah, tingkat kematian bayinya tinggi, masyarakat yang mengalami gizi buruk dan kekurangan gizi, semua ini bisa dikategorikan dalam kelompok marginal.

2. Seperti Tingkat harapan hidup, kematian bayi, kekurangan gizi dan gizi buruk pada masyarakat umum.

d). Secara Pendidikan:

1. Maknanya: sebuah kelompok masyarakat yang di dalamnya tingkat buta hurufnya tinggi, banyak yang tidak sekolah, maka kelompok masyarakat semacam ini dapat didefinisikan dal am golongan kelompok marginal.

2. Seperti: tingkat buta huruf, rasio bruto pendaftar sekolah, dll.
Kaum marjinal atau masyarakat marjinal adalah masyarakat kelas bawah yang terpinggirkan dari kehidupan masyarakat. contoh dari kaum marjinal antara lain pengemis, pemulung, buruh, petani, dan orangorang dengan penghasilan pas-pasan atau bahkan kekurangan. ${ }^{24}$

\section{c. Kriteria dan Indikator Marjinal.}

Sebenarnya tidak ada definisi tunggal untuk kelompok marginal, tapi ada beberapa kriteria atau indikator yang bisa memperjelas dan menggambarkannya.

Kriteria dan indicator marjinal berdasarkan subyeknya: menurut pendapat Sindu Hartanto ${ }^{25}$ adalah sebagai berikut

a). Secara Sosiologis:

1. yang termasuk kelompok marginal adalah buruh anak, seorang/ kelompok/masyarakat yang mendapatkan perlakuan tidak adil atau diskriminatif karena persoalan gender, seseorang atau kelompok masyarakat yang mengalami peminggiran sosial, dan masyarakat atau kelompok masyarakat yang hak asasinya terlanggar. Dengan demikian, individu atau kelompok masyarakat yang mendapat ketidakadilan/peminggiran karena persoalan-persoalan di atas tersebut, maka ia masuk dalam kategori marginal.

pada hari Selasa 30 Mei 2017 Pukul 22:06. WIB

24

https://www.erepublik.com/id/article/sosialist-ids-kaum-marjinal-adalahtanggungjawab-kita- 2259 034/1/20 diakses pada hari Selasa 31 Mei 2017 Pukul 10:15. WIB

25

https://sinduhartanto.wordpress.com/2011/01 /27/siapa-kelompok-marginal/ 
h). Secara Indeks Pembangunan:

- Sebuah kelompok masyarakat yang indeks pembangunannya rendah, yang meliputi pertumbuhan ekonominya rendah, pemerataan ekonomi juga timpang dan tidak merata, harapan hidup rendah, tingkat melek huruf rendah, tidak adanya kesetaraan gender dalam ruang publik, maka kelompok masyarakat semacam ini juga masuk dalam klasifikasi kelompok marginal. Yang juga masuk dalam kelompok marginal adalah kelompok $\mathrm{m}$ asyarakat miskin, yang ditunjukkan oleh rendanya pendapatan perkapita.

- Seperti: indeks pembangunan manusia, indeks pembangunan yang berkaitan dengan gender, dan indeks kemiskinan manusia

\section{d. Pembangian}

Masyarakat Marjinal dan Aplikasi Dakwah pada Masyarakat Marjinal.

Masyarakat marjinal pada dasarnya terbagi menjadi dua bagian yakni: Masyarakat Marginal yang Tradisional dan Masyarakat Marginal yang Tradisional Modern.

1). Masyarakat Marginal yang Tradisional

Pemikiran teologis yang melihat segala sesuatu keterbelakang-an umat lebih dilihat semata rencana Tuhan dan oleh karena itu tidak dilihat sebagai masalah utama. Akar pemikiran ini lebih pada konsep takdir yang telah disuratkan Allah jauh sebelum Tuhan menciptakan alam ini. Akar teologi seperti ini sering dikenal dengan golongan ahlusunah (Sunni). Pola dakwah dari masyarakat marginal lebih pada proses penyampaian pesan-pesan Islam yang cenderung pada semangat sabar yang terkadang disalahartikan. Para da'i dalam menyampaikan pesan cenderung mengajak masyarakat untuk lebih mengutamakan melihat realitas e). Secara Politik:

1. Individu atau kelompok masyarakat yang terhambat atau tidak diberi ruang untuk ikut berpartisipasi dalam pemilu, maka ia tergolong marginal (secara politik). Begitupun kelompok masyarakat yang tidak bisa mendapatkan kenyamanan dan selalu terancam baik dalam $\mathrm{m}$ asalah keamanan maupun dari kekerasan ia juga masuk dalam kategori marginal. Dalam konteks ini tentu pemenuhan dan penanganannya pun berbeda.

2. Seperti: partisipasi dalam pemilu, indeks korupsi, status keamanan, kriminal atau kekerasan

f). Secara Ekonomi:

1. Sebuah kelompok masyarakat maupun individu yang pendapatan perkapitanya rendah sehingga ia masuk kategori miskin, maka ia masuk dalam elompok marginal. Batas bawah pendapatan perkapita dalam hal ini berbeda-beda antara yang biasanya ditetapkan pemerintah maupun lembaga-lembaga international. Begitupun kelompok masyarakat yang meng-anggur dan tidak memiliki pekerjaan, ia juga masuk dalam kategori marginal.

2. Seperti: pendapatan domestik perkapita rendah, tingkat penganggur-an tinggi, dll.

g). Secara Ekologis:

1. Kelompok masyarakat yang sumber daya alamnya rusak, terksploitasi sehingga mereka tidak dapat memanfaatkannya lagi untuk kehidupan juga bisa dikategorikan marginal.

2. seperti: polusi lingkungan, kondisi sumber daya alam yang hancur sehingga tidak bisa berlanjut. 
lebih rasional dan sesuai dengan modernisme.

Materi dalam konteks dakwah adalah sesuatu hal yang disampaikan kepada mad'u dengan tujuan menjalankan syariat agama. Umumnya materi dakwah erat kaitannya dengan ajaran-ajaran yang disyariatkan oleh agama Islam. Muaranya adalah bagaimana materi disampaikan kemudian orang yang menerimanya mempunyai akhlak yang mulia. Pada tataran inilah materi harus disesuaikan dengan kondisi mad'u-nya.. Tidak mungkin antara satu mad'u dengan mad'u yang Iain sama dalam pengertian cara berpikir. Apabila setiap orang mempunyai cara berpikir yang tidak sama, maka bagaimana mungkin materi disamakan dalam penyampaiannya. Alhasil setiap orang akan menerima materi dengan mudah kemudian dengan pengetahuan yang didapatkan menjalankan apa yang menjadi kewajibannya. Maka, klasifikasi materi dengan memandang mad'u menjadi sebuah kewajiban. $^{26}$

Secara umum, materi dakwah adalah materi yang memuat aspek duniawi dan ukhrawi. Namun karena mad'u-nya adalah anak jalanan sebagai anggota masyarakat yang termarginalkan, konsep yang ditawarkan sebagai berikut:

\section{1) Materi Motivasi Diri.}

Materi pertama yang wajib disampaikan adalah motivasi diri, Iatar belakangnya adalah bahwa motivasi menjadi anak jalanan dikarenakan kemiskinan, artinya anak jalanan harus diberi bekal bahwa menjadi anak jalanan dalam pandangan sosial tidak layak, mereka harus bangkit dari prasangka bahwa hidup dalam

26 Syamsuddin. AB. Pengantar Sosiologi Dakwah. Kencana Prenada Media Group. Jakarta: 2016., hlm., 246-246 keterpurukan mereka sebagai sebuah janji Tuhan terhadap manusia yang bersabar adalah kehidupan yang baik kelak. Inilah yang menyebabkan golongan modernis meng-anggap bahwa golongan tradisionalis lebih cenderung pasrah kepada keadaan, termasuk dalam hal perkembangan di masyarakat. Namun begitu, sebagian dari kelompok tradisionalis ada pula yang mulai berupaya melakukan reinterpretasi, reaktualitas nilai-nilai yang dilembagakan dalam pesantren. Mereka umumnya bergerak pada tataran "wacana transformatif" dan diikuti oleh aksi-aksi yang memberdayakan. Wacana transformatif yang didengungkan dapat dilihat dengan seringnya mereka mengutip kaidah fikiah "pelestarian nilai lama yang masih relevan dan pencarian nilai baru yang lebih baik" sebagai semangat melepaskan diri dari perangkapperangkap keterkungkungan.

2. Masyarakat Marginal yang Modemis Cara berpikir yang melihat masalah keterbelakangan umat Islam sebagai akibat dari "ada yang salah" dalam teologi umat Islam yang dianut umat Islam saat ini yang cenderung fatalistik artinya, menurut mereka perlu ada penafsiran baru terhadap keseluruhan konsep keagamaan secara rasional. Pemikiran semacam ini berakar pada pemikir seperti Muhammad Abduh yang mendorong perlunya kembali akidah Islam yang benar, yang selanjutnya lebih sering disebut dengan gerakan pembaru. Pola dakwah yang mereka lakukan adalah dengan cara mempersiapkan umat Muslim baik secara teologis maupun teknis agar bisa berpartisipasi dalam develop-mentalisme. Bagi mereka, upaya pembaruan lebih dimaksudkan sebagai jalan untuk "mengubah sikap mental dan pandangan teologi" menjadi 
halangan. Tahapan yang ditempuh untuk selalu memberi motivasi, yaitu:

a) Mengetahui nama dan tempat tinggal,

b) Mengetahui latar belakang, baik sosial, pendidikan, dan eko-nomi.

c) Mengetahui karakteristik atau kepribadian yang dimiliki,

d) Mengetahui kebutuhan apa yang diinginkan. Keempat tahapan tersebut masih bisa ditambah dengan yang lain sesuai dengan kebutuhan yang ada.

Namun setidaknya keempat tahapan tersebut dapat menjadi acuan bagi seorang da'i untuk dapat menyampaikan materi kepada anak jalanan.

2) Materi Mengenai Pemberdayaan Hidup.

Materi yang selanjutnya disampaikan adalah materi yang berkenaan dengan pemberdayaan hidup. Dalam hal ini hal yang penting disampaikan adalah bagaimana cara mencari penghasilan yang tentunya dengan mengacu pada ajaran Islam yakni memenuhi asas syariah seperti mencari rejeki yang halal. Dengan pengarahan bagaimana mencari rejeki yang halal maka hidup mereka akan menjadi terarah dan tenang serta penuh barokah. Penyampaian materi ini diarahkan agar anak jalanan mampu mencari uang selain menjadi anak jalanan. Materi ini bisa berkenaan dengan kewira-usahaan di bidang keterampilan, peternakan, perikanan, bisnis, dan sebagainya. Penyampaian materi ini harus sesuai dengan potensi yang dimiliki setiap anak agar nantinya dapat diterima dan dapat dilaksanakan sesuai dengan kesanggupan masingmasing.

Penyampaian materi ini tidak terbatas kepada teoretiknya saja tetapi sekaligus praktiknya. Mereka pertama dibekali dengan teori-teori yang kemiskinan tidak harus menjadi anak jalanan, mereka masih bisa berkarya meski dalam keterpurukan. Para anak jalanan belum sadar dan belum paham betul mengenai praktik agama. Terlihat dari penampilan yang semrawut, pakaian selalu kotor, dan tubuh yang jorok. Dengan demikian, anak jalanan tidak terlalu memikirkan kehidupan akhirat. Fokus pikiran mereka terorientasi pada bagaimana dapat hidup layak bagai orang kaya. Sedikit sekali dari mereka yang mempunyai motivasi untuk bangkit dari anak jalanan. Praktik pemberian motivasi ini dapat diberikan di setiap kesempatan, hal ini digunakan dalam rangka membangun emosional antara anak jalanan dan da'i. Dengan hubungan emosional tersebut diharapkan dapat menjadi sebuah kelekatan, akhirnya tidak ada kecurigaan yang mendasar bagi anak jalanan terhadap da'i, bahkan jika memungkinkan selalu mendampingi mereka di kala letih dari aktivitasnya, justru mereka sangat senang jika ada seseorang yang mendampingi mereka belajar mengenai kehidupan baik dari sisi agama maupun berkarya dalam hidup. Adapun motivasi yang disampaikan berupa motivasi bahwa hidup adalah perjuangan, setiap orang berhak dan bisa hidup layak sesuai dengan apa yang dilakukannya, manusia adalah makhluk ciptaan Tuhan yang paling sempurna, manusia hidup di dunia tidak selamanya. Penekanan dalam materi motivasi ini adalah kebangkitan diri menuju pribadi yang mandiri. Kebangkitan ini didapat dari semangat hidup yang progesif. Memang seca-ra teknis membutuhkan waktu yang lama sampai mereka sadar dan tidak menjadi anak jalanan kembali. Namun demi tugas yang mulia dan kepedulian sesama, waktu bukan menjadi 
praktisi ekonomi (ekonom) bahkan psikolog. ${ }^{27}$

3) Materi Mengenai Agama. Materi agama adalah materi yang paling puncak dalam berdakwah, materi agama adalah tujuan utama dalam berdakwah. Maka, setelah anak jalanan sadar akan hidup dan mempunyai harta yang dirasa cukup sebagai bekal hidup, barulah materi agama disampaikan. Diharapkan materi agama mampu dicerna dengan sempurna dan dapat dipraktikkan dengan sempurna pula. Adapun materi agama yang perlu disampaikan, antara lain:

a) Materi yang berhubungan dengan akidah,

b) Akidah dalam pandangan agama adalah fondasi utama dalam beragama.

Dengan mengetahui akidah, maka seseorang akan me-ngetahui siapa Tuhannya, malaikat, kitab suci, nabi-nabi, dan sebagainya. Penekanan pada akidah akan berimplikasi pada ibadah yang dilakukan karena luasnya pengetahuan tentang akidah sejalan dengan apa yang diamalkannya. Maka, materi ini wajib disampai-kan kepada anak jalanan.

4) Materi yang Berhubungan dengan Syari'ah. Materi selanjutnya adalah tentang materi yang berhubungan dengan syariah. Hal ini juga sangat penting karena ketika akidah sudah tertancap dalam hati, maka syariah harus diajarkan kemudian. Materi syariah ini akan membantu seseorang dalam menjalankan ibadahnya bahkan mempermudahnya. Sebagai contoh, bagaimana anak jalanan akan bisa shalat jika tidak pernah diajarkan

27 Syamsuddin. AB. Pengantar Sosiologi Dakwah. Kencana Prenada Media Group. Jakarta: 2016., hlm., 249 dibutuhkan kemudian dilanjutkan dengan praktiknya. Prinsip yang digunakan adalah advokasi yang intensif, mereka selalu dikawal bahkan kemudian perlu mereka dibantu dari segi produktivitasnya dan distribusinya, jangan sampai materi yang sudah dicerna dan dipraktikkan mengalami kejumudan dan kebuntuan. Semakin sering mereka didampingi dan diperhatikan, maka semakin besar angka keberhasilan penyampaian materi mengenai pemberdayaan hidup. Karena itu adalah penting adanya pendamping dalam hal ini ulama dan aparat pemerintah

Penting untuk digarisbawahi bahwa materi pemberdayaan hidup harus benar-benar diajarkan secara serius. Hal ini mengingat bahwa persoalam materi ini yang menjadi faktor dominan dari keberadaan mereka sebagai masyarakat marjinal. Selain itu, pemberdayaan hidup dari segi ekonomi dikarenakan memang inilah yang menjadi dasar bagi berkembangnya anak jalanan. Materi ini sangat tepat bila dikaitkan dengan alasan anak-anak hidup di jalanan. Bila materi semacam ini tidak disampaikan, maka pengetahuan mereka mengenai mencari nafkah hanya terbatas menjadi pengamen, peminta, bahkan pencopet, dan sebagainya. Tentunya ketika menyampaikan materi ini harus dilakukan oleh orang-orang yang benar-benar ahli pada bidangnya. Sebagai contoh, ketika memberikan materi mengenai perikanan, maka yang wajib mengisi adalah orang yang berkecimpung di dunia perikanan. Jika harus melalui lembaga pemerintah, maka tepat jika mengundang pembicara baik dari para ulama ataupun para 
pemehaman teologi yang benar yakni teologi rasional. Dengan teologi rasional mereka akan menemukan pemahaman yang tepat tentang teologi dan tentang takdir.

Itulah beberapa materi dasar yang mesti diajarkan atau ditanamkan kepada masyarakat marjinal. Meski demikian, tentu saja akan menjadi lebih baik apabila materi tersebut ditambah dan dikembangkan secara terus menerus sesuai dengan kebutuhan dan perkembangan zaman yang semakin hari semakin kompleks, sehingga penanganan dan pembelajaran khususnya yang berkaitan dengan materi yang harus disampaikan kepada masyarakat marjinalpun selalu dikembangkan

\section{PENUTUP}

Masyarakat marjinal, meskipun tidak diharapkan kehadirannya, namun faktanya masyarakat atau kelompok marjinal selalu saja ada ditengahtengah kita. Karena itu masyarakat marjinal sesungguhnya merupakan masalah bagi kita semua. Dalam artian, kita harus selalu membantu mereka dengan cara memberi arahan dan memberdayakan mereka. Karena pada dasarnya mereka akan mampu memberdayakan diiri mereka apabila mereka diberi kesempatan. Selain itu, kita tidak boleh memandang mereka dengan sebelah mata. Karena mereka juga adalah manusia yang sama seperti kita yang ingin hidup secara layak dan bisa diterima oleh masyarakat. Karena itu jelas dalam hal ini kita baik sebagai akademisi, teoritisi ataupun praktisi terutama para ulama dan aparat pemerintah harus mengambil peran dalam membantu masyarakat marjinal dengan -salah satu caranya-adalah memberdayakan masyarakat marjinal agar mereka benar-benar berdaya dan mampu untuk hidup secara baik. Baik mengenai tata cara shalat yang benar. Materi syariah bisa berupa syariah tentang hukum, tata cara ibadah atau bahkan muamalah yang berkaitan dengan bagaimana bergaul dengan sesama manusia. Bergaul dengan sesama manusia (hablun minan nas) sangat relevan untuk disampaikan agar dalam pergaulan mereka dengan sesama manusia bisa menjadi jelas terarah dan berakhlakul karimah.

5) Materi yang Berhubungan dengan Akhlaq. Sebagai materi yang selanjutnya, materi akhlak menjadi tuntutan dalam penyelenggara-an materi, karena, seseorang akan dinilai baik manakala akhlaknya baik. Bagaimanapun pintarnya seseorang atau kaya raya tetapi ketika akhlaknya rusak, maka tetap dianggap bukan orang baik. Maka, penting bagi anak jalanan diajarkan mengenai akhlak sehingga mereka akan tahu bagaimana harus hidup dalam masyarakat. ${ }^{28}$

6). Materi yang Berhubungan dengan masalah Teologi. Materi yang tak kalah pentingnya untuk disampaikan pada masyarakat marjinal adalah materi tentang teologi. Masyarakat marjinal biasanya identic dengan ketidakberdayaan. Ketidak berdayaan ini muncul karena adanya keyakinan bahwa apa yang dia sandang yakni sabagai masyarakat marjinal karena mereka adalah keturunan yang terlahir dari masyarakat yang marjinal. Bahkan yang lebih parah lagi mereka beranggapan bahwa marjinalitas yang disandangnya karena takdir yang telah digariskan oleh Allah swt. Sikap atau pandangan teologis seperti ini harus dikikis habis dari diri mereka dengan memberi

\footnotetext{
${ }^{28}$ Ibid., hlm., 250.
} 
Moch. Ali Aziz, Ilmu Dakwah. Jakarta : Prenada Media 2004.

Murtadha Muthahhari, Masyarakat dan Sejarah, Bandung: Mizan, 1993.

Oos. M. Anwas, Pemberdayaan Masyarakat di Era Global. Bandung : Alfabeta. 2014.

Ropingi el-Ishaq. Pengantar Ilmu Dakwah. Studi Komprehensif dari Teori ke Praktek. Malang : Madani., 2016.

Sidi Gazalba, Masyarakat Islam Pengantar Sosiologi dan Sosiografi, Jakarra: Bulan Bintang, 1976.

Syamsuddin. AB. Pengantar Sosiologi Dakwah. Kencana Prenada Media Group. Jakarta: 2016.

W.J.S. Poerwadarminta. Kamus Umum Bahasa Indonesia, Jakarta : Balai Pustaka 1991. dari prespektik norma ataupun dari prespektif agama.

\section{DAFTAR BACAAN}

Badruddin HSubky. Dilema Ulama dalam Perubahan Zxmqn Jakarta: Gema Insani Press. 1995

Edi Suharto. Pembangunan Kebijakan sosial dan Pekerjaan sosial; Spektrum Pemikiran : Bandung ; Lembaga Studi Pembangunan STKS (LSP-STKS). 1996.

Hamdan Rasyid. Kaderisasi Ulama di Pesantren. Dalam Saifullah Ma'sum. Dinamika Pesantren (Telaah Kritis Keberadaan Pesantren Saat Ini). Depok: yayasan Islam Al-Hamidiyah dan yayasan Saifudin Zuhri. 1998.

Harry Hikmat. Strategi Pemberdayaan Masyarakat. Bandung Humaniora., 2013.,

http://www.google.co.id/\#q=arti+masy arakat+marjinal\&spf $=149615652$ 9661 diakses pada hari Selasa 30 Mei 2017 Pukul 22:06. WIB

https://sinduhartanto.wordpress.com/20 11/01/27/siapa-kelompokmarginal/ diakses pada hari Rabu 31 Mei 2017 Pukul 09:20. WIB

https://www.erepublik.com/id/article/sosialist-ids-kaum-marjinaladalah-tanggungjawab-kita-2259 034/1/20 diakses pada hari Selasa 31 Mei 2017 Pukul 10:15. WIB

M. Quraish Shihab. Membumikan AlQuran: Fungsi dan Peran Wahyu dalam Kehidupan Masyarakat. Bandung : Mizan. 1992. 